ISLLAC

Journal of Intensive Studies on Language, Literature, Art, and Culture

Vol. 1 No. 1 September 2017

\title{
CULTURAL LITERACY DEVELOPMENT BASED ON LOCAL ORAL- STORIES AS THE CULTURAL IDENTITY OF KEBONSARI ELEMENTARY SCHOOL
}

\author{
Tristan Rokhmawan ${ }^{1} \&$ M. Bayu Firmansyah ${ }^{2}$ \\ (tristanrokbmawan19890821@gmail.com_firmansyabbayu970@gmail.com) \\ STKIP PGRI Pasuruan
}

\begin{abstract}
In this research the researcher collects philology materials, local oral stories, forms stories in a story book and uses them as a basis for developing a literacy program based on local oral stories entitled Sekolah Berbudaya Lisan (SBL). By adopting ethnographic and philological methods the researchers collect local oral story data around the school to be transformed into a written form of children's stories in picture books. This storybook based on local oral stories becomes the foundation of the embodiment in developing and cultivating a literacy activity program which is done by combining 4D research and social engineering research methods. The SBL program was developed to create role models for social engineering activities for schools to develop the cultural behavior of oral literacy in their environment. SBL as well as making local oral stories as a distinctive characteristic that must be preserved. Schools become cultural centers of oral stories and preserved forms of local oral stories that are almost extinct because modern society has abandoned traditional oral storytelling.
\end{abstract}

Keywords: cultural literacy, local oral stories, school cultural identity

\section{INTRODUCTION}

There are at least four aspects underlying this research. First, the government program of the Republic of Indonesia through the Ministry of Education to develop a new curriculum system with the title of Curriculum 2013 (K13) to replace the previous curriculum, Curriculum 2006. Second, the existence of some curriculum content developed with K13 namely the development of school literacy movement, character education, cultural development, and the school as a cultural center. Third, 
ISLLAC

Journal of Intensive Studies on Language, Literature, Art, and Culture

Vol. 1 No. 1 September 2017

the fading of oral culture through oral storytelling in Indonesian society. Fourth, the loss of various forms of oral folklore in traditional Indonesian culture.

Since the introduction of the new curriculum 2013 (K13) that replaced the 2006 curriculum (KTSP 2006), the education system in Indonesia is much improved. Since 2013, the new curriculum continues to be piloted, revised and loaded by new strategies to improve the quality of education. Character education, cultural literacy, and cultural development are the most prominent additional content to be developed in the 2013 curriculum.

Overview of the literacy movement, the issue of the literacy movement in Indonesia has been rolled out since 2015 by the government, preceded by the launching of the School Literacy Program (Gerakan Literasi Sekolah / GLS) by the Ministry of Education and Culture. Symbolically, Minister Anies Baswedan has launched the GLS with the theme "Language of Growing Character"; by submitting a textbook reading book for 20 schools in DKI Jakarta as an initial material for literacy activities, last August 2015. The development of GLS is based on the Regulation of the Minister of Education and Culture No. 21 of 2015 on the Growing of Character.

GLS is a movement that strengthens the movement of moral character as stated in the Regulation of the Minister of Education and Culture No. 23 of 2015. One of the activities in the movement is a 15-minute activity of reading non-learning books before the start of study time. This activity is conducted to foster interest in reading learners and improve reading skills so that knowledge can be mastered better. (Director General of Primary \& Secondary Education Kemendikbud (1), 2016 Director General of Primary and Secondary Education Kemendikbud (2), 2015). From this exposure can be concluded then that the school literacy movement is able to accommodate the goal of character development that also became the concentration of character education.

Cultural elements are developed alongside curriculum development. One of them by strengthening the role of schools as education providers to carry out the 
ISLLAC

Journal of Intensive Studies on Language, Literature, Art, and Culture

Vol. 1 No. 1 September 2017

mandate of preservation of cultural material and local wisdom of Indonesian society. As we know, Indonesia is a country rich in traditional tribes, races, and customs. In turn, the school is expected to be able to become a protector, conservationist, and development center of the cultural elements. In addition to cultural literacy development, the government through Permendikbud 61 Th. 2014 on the conceptual reference of the development of socio-economic conditions and the characteristics of educational units requires that schools be able to carry out the mandate as a cultural center (Dit PSMA, 2015). As a cultural center, schools need to innovate in order to have a visible image of the forms of school culture. One way is to realize the GLS as an icon of school culture. In addition to realizing its distinctive cultural image, the school also needs to realize the culture of the local community as one of its trademarks.

On the other hand outside of education, but still related, is about the oral culture of Indonesian society. In traditional Indonesian society, oral culture develops in the form of storytelling activities. Cultural storytelling is done for various purposes. In the family environment, storytelling activities are usually done to deliver children's sleep or leisure time. In addition, storytelling activities are also often a vehicle for parents and religious leaders to convey cultural normative, customary, and religious teachings (Dananjaja, 2002).

The Cultural story began to be abandoned with the progress of the digital world (Rokhmawan, 2015). This culture began to fade with the advancement of the digital world and the modernization of wireless communication devices. Today people prefer to communicate remotely and digitally. The forms of oral communication with the nearest person, especially to just tell a story began to be considered boring. The storytelling culture was abandoned because of the low public awareness of the importance of direct contact with children in the home environment both physically and verbally. It is this physical and verbal contact that will create an inner bond between the child and the parent. Proximity can provide space for parents to instill positive character and life values in children. Thus, storytelling activities with 
ISLLAC

Journal of Intensive Studies on Language, Literature, Art, and Culture

Vol. 1 No. 1 September 2017

positive character content and life values are one of the most important things to do and be effective in educating children within the family. The loss of awareness of this causes the storytelling culture began to be abandoned by most of the Indonesian families.

When the storytelling culture began to be abandoned, then its function will also be lost. Children will have a "social and cultural identity blurriness" of themselves because they can not identify themselves for lack of exposure to the concept of their culture. Sociopsychologically, children in family life have no closeness both physically and emotionally with their parents. Furthermore, adolescents lose attachment to their parents, create an attachment to others outside the family (which may be negative), and gradually feel loose and need to break away from family ties. Moreover, teenagers will live with the world outside freely, uncontrollably and constrained.

In addition to the problems in the culture of storytelling that is needed in building the literacy culture, the author also highlights the problem of the local oral story that is threatened with extinction (Rokhmawan, 2016). The oral narrative in question is a myth, a legend, and a fairy tale (Bascom W., 1965). During this time, children may only know a certain story like the story of the archipelago or animation that has been widely known and easily accessible via the internet and television. Even if there are oral stories/folklore, children know more about the story of the archipelago like Malin Kundang or international fairy tale like Snow White and Sleeping Beauty rather than the oral story in its own region. Local oral literature is currently threatened with extinction because people no longer mention it often. In addition, the children's interest in this story is also defeated by other stories that they easily get from television, the Internet, or modern reading books like novels and comics made by Disney, Marvel, Nickelodeon, and so on.

In the context of the local area around Kebonsari Elementary School, researchers found some forms of oral literature such as the story of the kiai (religious leaders of Muslim in Java) and some of other legends and tales that have not been widely known by people from outside of this area. These local oral stories are verbally 
ISLLAC

Journal of Intensive Studies on Language, Literature, Art, and Culture

Vol. 1 No. 1 September 2017

orchestrated in the community, spoken on various occasions such as religious events, baul (memorial of death) of religious leaders, daily religious activities, or in the daily life of the local community. Through this folklore, the hereditary community gives advice implied through the content of the story. It is this trust that in turn helps to build the quality of generations' understanding of customary norms, local wisdom, and good character and society. but unfortunately, once again these stories are experiencing a speaker's crisis, where society no longer has a commitment to keep telling.

Given the facts and problems above, the researchers feel there should be efforts to contribute to the literacy movement in Kebonsari Elementary School. These efforts will also be a way of solving the conservation efforts of local oral stories that have only lived in the oral culture of the surrounding community. Researchers have the ultimate goal of research to carry out literacy activities in one package program. Through this series of literacy programs, researchers also bring up local oral stories as literacy objects. In general, these local oral-based literacy-based cultures can create a school culture which in turn will be a special feature of Kebonsari Elementary School. To realize these ideas, researchers are interested in establishing a study entitled "Cultural Literacy Development based on Local OralStories as the Cultural Identity of Kebonsari Elementary School "

\section{METHOD}

The outline of this research is divided into two forms: 1) the results of research on some local oral stories around the school and 2) the result of the project of developing the literacy culture of the school based on the local oral story. The research stages for each outcome follow Spradley's (1997) and Dananjaja (2002) suggestions for local oral story research, and Osterloo (2008) and Thiagarajan, Semmel, \& Semmel (1974) suggestions for program development and social engineering research. 
ISLLAC

Journal of Intensive Studies on Language, Literature, Art, and Culture

Vol. 1 No. 1 September 2017

To achieve the target of the research, the researchers set two stages in general in this research, which are 1) the local oral story-finding stage and the preparation of short story book collection, and 2) the implementation of the school literacy movement. The next stage ends with evaluation and dissemination of research results.

Storytelling through sub-phases developed from ethnographic research methods (Spradley, 1997) and philology (Dananjaja, 2002): finding sources of stories, exploring story information, recording, transcription, transliteration from local languages into Indonesian, story validation through the process comparison of sources, compose the whole story according to the structure (scaffolding) of the narrative prose text, and complete the presentation of the story with the illustration of the picture. The implementation of the school literacy movement through the subphases of planning activities and composing a program titled "Sekolah Berbudaya Lisan (SBL)", program socialization, teacher training and modeling students, and oral literacy in various corners of the school by utilizing a local collection of oral stories.

Implementation of literacy movement titled SBL as a form of school culture subsequently became the school's cultural identity in the realm of appearance refers to the fiscal and social engineering of the behavior of school citizens. Fiscal matters that embody the school culture are the existence of various literacy-based infrastructures such as wall magazines, bookshelves, reading rooms, and libraries. While the form of conditioning on the behavior of school residents can be done by doing social engineering methods (Osterloo, 2008). Social engineering methods include activity purchasing for socialization and briefing of knowledge and skills on literacy activities, role modeling, habituate, monitoring, evaluating, and upgrading activities. This activity is a whole school program (comprehensive school program). That way, this culture will not be valid for a moment but will continue to be implemented as a culture passed down from generation to generation by every citizen of the school.

In general, all research activities are based on research and development $(\mathrm{R} \&$ D) approach with 4-D model suggested by Thiagarajan, Semmel, and Semmel (1974). The 4-D model is used for research of learning device development. This model 
ISLLAC

Journal of Intensive Studies on Language, Literature, Art, and Culture

Vol. 1 No. 1 September 2017

consists of 4 methodical stages of define, design, develop, and disseminate. In the Indonesian discussion, this model can be adapted in 4-P, which is defining, designing, developing, and disseminating.

The development research was conducted at Kebonsari Elementary School, Pasuruan City, East Java, Indonesia. The development of the literacy movement under the name of the SBL program is conducted covering all members of the community within the school. While the source of oral stories used collected from public utterances around the school, limited to the scope of Pasuruan.

\section{FINDINGS AND DISCUSSION}

The research produced two general outcomes: (1) the formation and packaging of local oral stories and (2) the application and culture of literacy movements in schools. These two outcomes can be spelled out in four things that need to be explained and discussed: (1) local oral story form, (2) children's storybook form developed from local oral stories, (3) the application of literacy movements in schools, and (4) tips on culture of literacy movements in schools.

In this research the researcher succeeded in developing 10 story titles including (1) Kiai Sepuh and Jackfruit Traders, (2) Mbah Slagah and Den Ayu Beri, (3) Kindness of Mbah Dacim, 4) Mbah Darim and Her Dog, 5) Kiai Hamid's Sandals, (6) Mbah Salim and The River Jinn, (7) KH Thoyyib Bin Abd. Salam, Jamu merchant who is the place to ask questions, (8) Modesty Behind Mbah Mas Imam's Umbrella, (9) KH Abdul Ghofur's prayer and blessing, and (10) Kiai Sepuh and The Rich Man who asked to build a mosque.

The ten story titles are each transformed into a picture story book. Researchers use this storybook as the basis for implementing the SBL program. This program was developed to target various aspects of the system, organizing, personnel, and the provision of facilities and equipment to support the application of literacy culture based on local oral story tradition in Kebonsari Elementary School. In accordance with the social engineering method (Osterloo, 2008), SBL programs 
ISLLAC

Journal of Intensive Studies on Language, Literature, Art, and Culture

Vol. 1 No. 1 September 2017

become role modeling. The culture is carried out by doing routine activities as habituation, monitoring its development, evaluating, and developing various activities of local oral story literacy (upgrading activity).

\section{Development of Oral-Local Stories}

Local oral stories are collected from the area around the main research site (Kebonsari Elementary School) and are limited to the administrative area of Pasuruan. Because there are many local oral stories in this region, the researchers give the following limits: (1) story character is a Muslim cleric who has died and is respected by Pasuruan society dominated by Muslim, (2) the story theme content is acceptable and feasible to read by children (under 18 years old), and (3) theme content contains good normative message / information to the reader. Once collected, the story is developed in the form of narrative prose with generic structure of abstraction, orientation, complication, evaluation, resolution, and coda. Each section of the structure works properly to complement the body of the story so that the theme, character, storyline, core issues, endings, and message can be clearly accepted by the children. The content of the story is diverse but it all leads to a useful moral message for children. These moral messages include messages to (1) maintain the faith of Islam, (2) worship well, (3) do good to others, (4) avoid reprisals of bad deeds/karma, and (5) trust the privileges possessed by the pious people as the gift of Allah Subhanahu Wata'ala, the God of Muslims.

In traditional literary studies, these stories belong to the oral folklore of oral narrative prose. This narrative oral prose may be a mythical, legend, and fairy tale (Bascom W., 1965; Dananjaja, 2002; Bascom W., 1954; Rokhmawan \& Firmansyah, 2015). The three are distinguished by their different characteristics. In general, all three equations are in the form of traditional / traditional narrative prose. Moreover, they differ in storytellers, storytelling, setting / time and place background, attitude to the existence of the story (aptitude), character and character figures, and the level of public confidence in the story. The above oral literary forms are scattered throughout 
ISLLAC

Journal of Intensive Studies on Language, Literature, Art, and Culture

Vol. 1 No. 1 September 2017

the region and local culture as part of cultural outcomes in a collective society, each collective must have its own oral literature.

Oral literature is an oral expression of a cultural community of a community or collective society spread across various plurality ethnic groups, form, form, and theme; function also varies. Local oral literature is a type of folklore or oral folklore that is collectively spoken by a society within the local scope of its territory. Local territory, in this case, refers to a community with certain territorial and cultural / ethnic boundaries. This type is distinguished from the oral literature of the archipelago spoken in a wider scope (Rokhmawan, 2016; Rokhmawan \& Firmansyah, 2015).

Stories with prominent Islamic clerics or leaders who have been collected by researchers is an oral expression of santri / Muslim society in the city of Pasuruan. In a society with a cultural background of Muslims, oral literature in this area many tangible religious narratives and the story of religious figures. Its function is very distinctive. In addition to including the value of moral teaching, this form of localoral literature is highly respected and even sacred existence.

Communities form a collective agreement on their belief in these forms of oral culture. Violations of trust are even thought to be causing bad things so that the public feels the need to preserve their sustainability by telling these stories from timeto-moment transcendence. In addition, the public believes that every story leaves many tips, mandates, and moral teachings and wisdom for the people.

The oral narrative brings the society in the mystical fantasy of the irrational belief that we call the myth. Instead of useless, myths can be regarded as people's way of life. The myth is also used as a guide in teaching a wisdom for people who have it (Panuti Sudjiman in Lantini, 1996; Bacon in Danandjaya, 2002; Haviland, 1985; Rokhmawan \& Firmansyah, 2015). The storytelling activities have functions in accordance with the oral story functions spoken. There are at least 8 functions to tell oral stories among them: (1) propaganda function, (2) ideological projection function, 
ISLLAC

Journal of Intensive Studies on Language, Literature, Art, and Culture

Vol. 1 No. 1 September 2017

(3) recreative function, (4) didactic / educational functions, (5) aesthetic function, (6) morality function of legalization of norms and social institutions, (7) the functions of moral coercion and supervision of social norms and institutions, and 8) religious functions (Rokhmawan, 2016; Rokhmawan \& Firmansyah, 2015). Trust in such myths, legends, and fairy tales is a sign of the triumph of local oral literature in a society of its time.

\section{Story Book Development}

The form of children's story books developed from local oral stories is transformed in the form of a children's story book with a landscape page format with a size of $13 \times 19 \mathrm{~cm}$. This book comes with illustrations to support storytelling. The illustrations used are children's illustrations with colored cartoon genres. Coloring using RGB (Red-Green-Blue) digital coloring. RGB is also called additive color or lighting color with bright, fresh, and fun characters, suitable for children. Fonts on conversation balloons using the Arial Rounded MT Bold font. Overall, the image processing is done digitally using Adobe Photoshop CS 6 software.

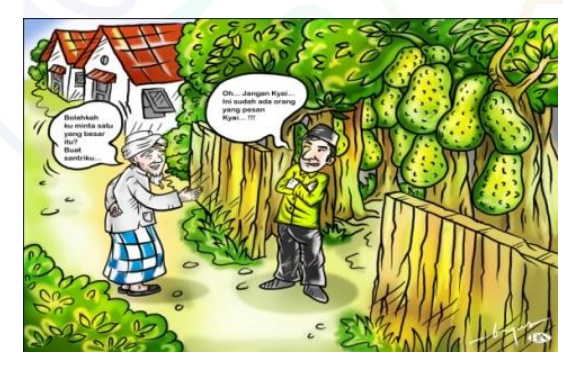

Figure 1 : Story illustration design

\section{Literacy Program Development}

The application of literacy culture is packed with the SBL program as a distinctive identity program in Kebonsari Elementary School. This program was developed to target various aspects of the system, organizing, personnel, and the provision of facilities and equipment to support the application of literacy culture based on the tradition of local oral stories. 
ISLLAC

Journal of Intensive Studies on Language, Literature, Art, and Culture

Vol. 1 No. 1 September 2017

In the aspect of the system, the development of Kebonsari Elementary School is done by completing the vision and mission of school and identity unit and school program in book one on the Education Unit Level Curriculum (Kurikulum Tingkat Satuan Pendidikan/KTSP) document. KTSP is an operational curriculum developed by and implemented in each educational unit. KTSP is developed, defined and implemented by each educational unit with reference to the 2008 National Standards for Education and Curriculum Standards. The school's vision-mission is complemented by material that leads to the application of cultural literacy and cultural preservation. In the KTSP document, a variety of school identity statuses that are characterized by the preservation of local oral stories and cultural traditions, school vision and mission that lead to the application of cultural literacy and cultural preservation, as well as the addition of the SBL program as the school's strategic program on Educational Objectives.

In the organizing and personal aspects, the school develops groups of teachers and students with oral literacy. This group consists of several teachers and students who will be the model of the activity of oral storytelling in the school environment. Activities can be centered at multiple points of literacy such as library rooms, classrooms, and representative open parks for teachers and students to develop an oral storytelling culture.

In the aspect of providing facilities and equipment, researchers with school participation provide several means to support literacy activities in SBL programs. Some of the facilities and equipment provided are representative learning spaces for storytelling activities, library rooms that store various sources of stories, green open spaces equipped with comfortable seating spots for storytelling activities, bookcases in every classroom and at some corners of the page, and wall magazine boards that can be exploited to develop a culture of literacy, reading and storytelling, based on oral-local stories. 
ISLLAC

Journal of Intensive Studies on Language, Literature, Art, and Culture

Vol. 1 No. 1 September 2017

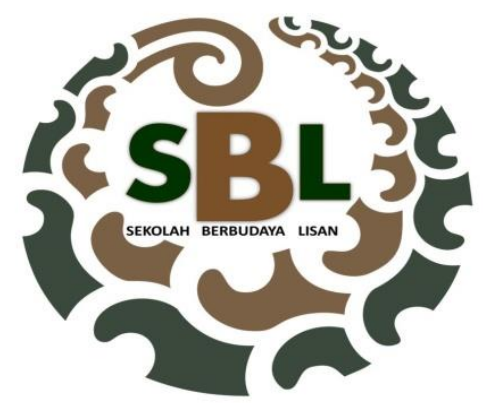

Figure 2 : SBL program logo

The SBL program became a special feature set up at Kebonsari Elementary School. In accordance with the Regulation of the Minister of Education and Culture no.61 Th. 2014 (Dit PSMA, 2015) on the conceptual reference of developing socioeconomic conditions and the characteristics of educational units, schools as cultural centers innovate to have a visible image of the forms of school culture. This imagery is realized with the SBL program.

In addition to realizing its distinctive cultural image, the school also needs to realize the culture of the local community as one of its trademarks. Utilizing the concept of developing a school culture through the appearance of the school, the school establishes and presents itself as a local oral literary cultural heritage. In accordance with local potential in the area, the school becomes a place where every citizen is an active speaker of all kinds of oral literature in his area. Schools utilize myths, legends, and fairy tales to become literary materials that are then told from generation to generation in the school.

\section{Cultivate Literacy Activities}

The culture of literacy movement at Kebonsari Elementary School is inseparable from the school community's competence in implementing various activities undertaken in the SBL program. In accordance with the social engineering method (Osterloo, 2008), SBL programs are a role model of literacy culture. The culture is carried out by doing activities continuously as habituate, monitor its 
ISLLAC

Journal of Intensive Studies on Language, Literature, Art, and Culture

Vol. 1 No. 1 September 2017

development, evaluate, and develop activity of oral literacy of local story (upgrading activity). With these stages, it is expected that the SBL movement not only applies ceremonial and ends soon, but can be applied in a long time as a habit even in the life of society in the school. As a habituation, in one-year post-socialization and SBL program launching, the researcher conducted full assistance to the school community to continue doing oral literacy activities in various places and time within the school environment. The teacher can perform oral literacy activities using 15 minutes of literacy at the beginning of the lesson. Students are literate orally outside the classroom using the available tools and equipment. Developments are monitored by establishing indicators of the intensity of oral literacy practices by teachers, students, and other schoolchildren. Evaluation is done to know the problems in the implementation and how to overcome them. Some of the problems that often arise are the reluctance of school residents to perform oral literacy activity steadily. However, this can be overcome by applying special scheduling to perform oral literacy activities. Oral literacy activities are developed in various ways such as increasing the intensity of activities, increasing the stories/literacy materials, to holding events such as oral literacy competitions and the selection of oral literacy ambassadors.

\section{CONCLUSIONS AND SUGGESTIONS}

In this research, the researcher gets two general conclusions of research related to (1) form and packing of the oral-local story and (2) application and culture of literacy movement in school. Local oral stories around the school can take the form of narrative prose stories of myth, legend, and fairy tales that are spoken in the form of oral culture. Stories in this oral culture can be preserved by packing them in storybook form. One of them with the form of children picture story. Story children's stories can be presented in such a way as to design an interesting, colorful, illustrated cartoon child, and contains stories that can give moral teachings for children. That way the value of the oral-local story as a source of advice will remain conveyed timeless. Furthermore, this local oral story-based storybook can be a tool for 
ISLLAC

Journal of Intensive Studies on Language, Literature, Art, and Culture

Vol. 1 No. 1 September 2017

implementing a literacy program with the headline of Oral Culture School / SBL program targeting the development of various aspects of the system, organizing, personnel, and the provision of facilities and equipment to support the application of literacy culture based on the tradition of oral- local. SBL programs can be a role modeling to develop cultural activity of oral literacy. But not enough to arrange a series of programs, culture must be followed up continuously by doing activities regularly as habituation and develop literacy activities until the activity can be entrenched.

\section{REFERENCES}

Bascom, W. (1954). Four Function of Folklore. The Journal of American Folklore, 333-349.

Bascom, W. (1965). The Form of Folklore : Prose Narrative. The Journal of American Folklore, Vol. 78, No. 307 , 3-20.

Dananjaja, J. (2002). Folklore Indonesia : Ilmu Gosip, Dongeng, dan Lain-lain. Jakarta: Pustaka Utama Grafiti.

Dharma, S. (2015). Penumbuhan Budi Pekerti dan Pengembangan Budaya Literasi. Sosialisasi Bansos Guru SMA. Solo : Dit. PSMA Kemendikbud.

Dirjen Pendidikan Dasar \& Menengah Kemendikbud (1). (2016). Desain Induk Gerakan Literasi Sekolah. Jakarta: Dirjen Pendidikan Dasar \& Menengah Kemendikbud.

Dirjen Pendidikan Dasar dan Menengah Kemendikbud (2). (2015). Buku Saku Gerakan Literasi Sekolah. Jakarta: Dirjen Pendidikan Dasar \& Menengah Kemendikbud.

Dit. PSMA. (2015). Panduan Peningkatan Citra Sekolah Melalui Penampilan, Pelayanan, dan Prestasi Sekolah Menengah Atas. Jakarta: Dirjen Pendidikan Menengah Kemendikbud.

Hadnagy, C. (2011). Social Engineering - The Art of Human Hacking. UK: Wiley Publishing.

Litbang Kemdikbud. (2015). Mendikbud Luncurkan Gerakan Literasi Sekolah. Retrieved on May 20, 2016, from litbang.kemdikbud.go.id: http://litbang.kemdikbud.go.id/ 
ISLLAC

Journal of Intensive Studies on Language, Literature, Art, and Culture

Vol. 1 No. 1 September 2017

Osterloo, B. (2008). Managing Social Engineering Risk - Making Social Engineering Transparent. Netherlands: Atos Consulting.

Peursen, C. A. (1988). Strategi Kebudayaan. Yogyakarta: Kanisius.

Rokxhmawan, T \& M.B. Firmansyah. (2015). Bangunan "Kerajaan Surgawi": Kepercayaan Irasional dan Fungsi Sosial dalam Legenda Kiai Sepuh. Jurnal Litrasi Volume 1, No.1, Pg.16-38.

Rokhmawan, T. (2016). Mengakrabkan Budaya Lisan dan Penyelenggara Pendidikan sebagai Upaya Merevitalasasi Kesusastraan Lisan-Lokal. Seminar Nasional Bahasa dan Sastra Indonesia - Nitisastra 1. Malang: Pascasarjana Universitas Negeri Malang.

Santayana, G. (2016). Ancient Myth, Religion, and Philosophy. Retrieved on February 2, 2016, from www.centerforfutureconsciousness.com: http://www.centerforfutureconsciousness. com/pdf_files/Readings/AncientMythPhil.pdf

Sarapik, V. (2000). Artist and Myth. Electronic Journal of Folklore (Folklore Vol. 15) by the Folk Belief and Media Group of ELM .

Soedjijono. (2002). Legenda Pulau Bawean (Kajian dengan Pendekatan Arketipal).

Prosiding Seminar Akademik, (p. Volume 2).

Spradley, J. P. (1997). Metode Etnografi. Yogyakarta: Tiara Wacana.

Wellek, R., \& Warren, A. (1990). Teori Kesusastraan. Jakarta: Gramedia. 